\title{
PENERAPAN PEMBELAJARAKONTEKSTUAL UNTUK MENINGKATKAN HASIL BELAJAR MATERI POKOK KOPERASI PADA MATA PELAJARAN ILMU PENGETAHUAN SOSIAL KELAS IV SD NEGERI TURI JETIS PONOROGO
}

\author{
Ika Lestari Widodo \\ Pendidikan Dasar Pascasarjana Universitas Negeri Surabaya
}

\begin{abstract}
Abstrak
Penelitian ini bertujuan untuk mendeskripsikan penerapan pembelajaran kontekstual untuk meningkatkan aktivitas guru, aktivitas siswa, dan hasil belajar IPS pokok bahasan koperasi. Jenis penelitian ini adalah deskriptif kuantitatif dengan desain penelitian berupa Penelitian Tindakan kelas (PTK) yang dilaksanakan dalam 2 siklus. Subjek penelitian ini adalah 25 siswa kelas IV SDN Turi Jetis Ponorogo. Teknik pengumpulan data dilakukan dengan observasi dan tes. Observasi digunakan untuk mengamati kegiatan guru dan siswa selama proses pembelajaran kontekstual, dan tes digunakan untuk mengukur hasil belajar siswa. Hasil penelitian menunjukkan bahwa aktivitas guru setelah melaksanakan pembelajaran kontekstual mengalami peningkatan. Aktivitas siswa dan hasil belajar siswa juga mengalami peningkatan. Pada siklus I, aktivitas guru adalah 70\%, aktivitas siswa 73,5\%, dan hasil belajar siswa $60 \%$. Pada siklus II, aktivitas guru 90\%, aktivitas siswa $88 \%$, dan hasil belajar siswa 92\%. Berdasarkan hasil tersebut dapat disimpulkan bahwa penerapan pembelajaran kontekstual pada pelajaran IPS pokok bahasan koperasi di kelas IV SD Negeri Turi Jetis Ponorogo dapat meningkatkan aktivitas guru, aktivitas siswa dan hasil belajar siswa.
\end{abstract}

Kata Kunci: Pembelajaran kontekstual, koperasi, hasil belajar.

Abstrak Bahasa Inggris

This study aims to describe implementation of the contextual learning to improve teacher activities, students activities, and learning outcomes of social study in cooperative material. This study is descriptive quantitative with classroom action research design

which is implemented in two cycles. The subject was 25 fourth grade students of SD Negeri Turi jetis Ponorogo. The data collection used observation and test to measure the learning outcomes of the students. The results show that the teacher activities after using the contextual learning has increased. The students activities and their learning outcomes has increased. On the cycle I, the teachers activities was 70\%, the students activities was $73,5 \%$, and the students learning outcomes was $60 \%$. On the cycle II, the teacher activities was $90 \%$, the students activities was $88 \%$, and the students learning outcomes was $92 \%$. Based on those results can be concluded that the implementation of the contextual learning of social study in cooperative material in fourth grade students of SD Negeri Turi Jetis Ponorogo can improve the teachers activities, the students activities, and the students learning outcomes.

Key Words: Contextual learning, cooperative, and Learning Result.

\section{PENDAHULUAN}

Metode mengajar yang dipakai guru sangat memengaruhi keberhasilan dalam kegiatan belajar mengajar. Guru diharapkan mampu mengajak siswa tidak hanya tahu tapi paham dengan apa yang diajarkan. Siswa selama ini belum memahami makna dari pelajaran yang diberikan oleh gurunya. Dengan siswa mengetahui makna maka siswa akan lebih mudah memahami setiap pengetahuan dan memiliki ketrampilan sosial yang diharapkan. Siswa yang kritis tentu akan berusaha mencari makna dari pelajaran yang diberikan oleh gurunya. Makna bisa siswa dapatkan ketika mereka dapat mengaplikasikan dalam kehidupan seharihari. Menurut Piaget (dalam Ibrahim dan Nur, 2008:28) pengajaran yang baik harus melibatkan anak ke dalam situasi di mana anak mandiri melakukan eksperimen, yaitu mencoba segala sesuatu untuk melihat apa yang terjadi, memanipulasi tanda-tanda dan simbol, mengajukan pertanyaan dan menemukan jawaban sendiri, serta mencocokkan apa yang ia temukan pada saat yang lain. Pendidikan IPS seperti yang disampaikan oleh Soemantri (Sapriya, 2009:14) bahwa pendidikan IPS merupakan pelajaran yang mempunyai peran dan fungsi strategis dalam usaha pembentukan warga Negara yang baik dan handal

Sesuai dengan tujuan pembangunan nasional, dan merupakan program pendidikan yang baik dan memasyarakat. Salah satu pendekatan yang bisa dipakai guru untuk membantu siswa menemukan makna dalam pelajaran IPS adalah dengan 
pendekatan kontekstual. Karena ciri utama dari pendekatan kontekstual adalah menemukan makna dari suatu pelajaran. Siswa dibimbing untuk mampu mengaitkan dengan keadaan lingkungan sekitar. Siswa menemukan, mengalami sendiri serta membangun pengetahuannya sendiri. Menurut Muchith (2008:2), pembelajaran kontekstual memuat kemampuan guru dalam melaksanakan proses pembelajaran terutama yang lebih menitikberatkan pada upaya pemberdayaan siswa. Pembelajaran dilaksanakan dengan memperhatikan potensi siswa, sarana pembelajaran, situasi dan kondisi, serta memperhatikan tujuan pembelajaran yang ingin dicapai. Hasil yang diharapkan dari pembelajaran kontekstual menurut Poedjiad, (2005: 98) adalah untuk meningkatkan prestasi belajar siswa melalui peningkatan pemahaman makna materi pelajaran yang dipelajarinya dengan mengaitkan antara materi yang dipelajarinya dengan konteks kehidupan sehari-hari. Berdasarkan pengamatan di SDN Turi Jetis Ponorogo, guru melakukan pembelajaran IPS materi koperasi masih menggunakan metode ceramah. Guru menerangkan materi tanpa memberi kesempatan bagi siswa untuk menemukan sendiri dan memecahkan masalah yang ada. Hasilnya bisa dilihat dari nilai ulangan yang masih jauh dari KKM. Permasalahan yang demikian terjadi pada pembelajaran IPS Pokok Bahasan koperasi pada siswa kelas IV SD Negeri Turi. Dengan Kriteria Ketuntasan Minimal (KKM) 65 untuk mata pelajaran IPS dari jumlah siswa sebanyak 25 siswa, ada 12 anak (48\%) yang mencapai nilai di atas nilai standar KKM. Jadi masih ada 13 siswa yang belum tuntas belajar atau nilai belajar IPS. Diperlukan sebuah inovasi pembelajaran untuk mengatasi masalah yang ada. Berdasar uraian tersebut penulis akan melakukan penelitian tindakan kelas dengan judul "Penerapan Pembelajaran Kontekstual Untuk Meningkatkan

Metode Penelitian ini menggunakan pendekatan penelitian kuantitatif. Penelitian ini menggunakan data berupa angka. Metode penelitian kuantitatif dapat diartikan sebagai metode penelitian yang berlandaskan pada filsafat positivisme, digunakan untuk meneliti pada populasi atau sampel tertentu. Jenis penelitian ini adalah pengembangan yang berupa Penelitian Tindakan Kelas untuk meningkatkan hasil belajar siswa pokok bahasan koperasi mata pelajaran IPS di kelas IV SD Negeri Turi Jetis Ponorogo. Penelitian dilakukan dalam beberapa siklus. Pada setiap siklus terdiri empat tahap yaitu perencanaan (planning), pelaksanaan (action) dan pengamatan (observation), refleksi (reflection), dan revisi (revised).

\section{HASIL DAN PEMBAHASAN}

Data yang dikumpulkan dalam penelitian ini adalah aktivitas guru, aktivitas siswa, dan hasil belajar siswa.

Tabel 1 Hasil Pengamatan Aktivitas Guru Siklus I

\begin{tabular}{|c|c|c|c|c|c|c|c|}
\hline \multirow{2}{*}{ No } & \multirow{2}{*}{ Kategori Pengamatan } & \multicolumn{5}{|c|}{ Skor Perolehan } \\
\cline { 3 - 7 } & & P1 & P2 & $\sum$ & $\begin{array}{c}\text { Rata- } \\
\text { Rata }\end{array}$ & $\%$ \\
\hline 1 & Memulai pehajaran & 3 & 3 & 6 & 3 & 60 \\
\hline 2 & Komponen kontekstual & \multicolumn{5}{|c|}{} \\
\hline & a. Kontruktivisme & 4 & 3 & 7 & 3,5 & 70 \\
\hline & b. Menemukan & 3 & 3 & 6 & 3 & 60 \\
\hline c. Bertanya & 3 & 4 & 7 & 3,5 & 70 \\
\hline d. Masyarakat belajar & 3 & 4 & 7 & 3,5 & 70 \\
\hline e. Pemodelan & 4 & 4 & 8 & 4 & 80 \\
\hline f. Penilaian autentik & 4 & 4 & 8 & 4 & 80 \\
\hline g. Refleksi & 4 & 3 & 7 & 3,5 & 70 \\
\hline Jumlah & 28 & 28 & 56 & 28 & 560 \\
\hline Rata-rata & $\mathbf{3 , 5}$ & $\mathbf{3 , 5}$ & 7 & 3,5 & 70 \\
\hline Persentase & $\mathbf{7 0}$ & $\mathbf{7 0}$ & $\mathbf{7 0}$ & 70 & \\
\hline
\end{tabular}

Keterangan:

$5=$ Sangat baik, $4=$ Baik , $3=$ Cukup, $2=$ Kurang baik, 1 = Tidak baik

Persentase keberhasilan:

$81 \%-100 \%=$ Sangat baik, $61-80 \%=$ Baik, $41 \%-$ $60 \%=$ Cukup, $21 \%-40 \%=$ Kurang (Arikunto, 2008:126)

\begin{tabular}{|l|l|l|l|l|l|l|l|}
\multicolumn{9}{c}{ Tabel 2 Hasil pengamatan aktivitas siswa siklus I } \\
\hline \multirow{2}{*}{ No } & \multirow{2}{*}{ Aspek Yang Diamati } & \multicolumn{2}{|c|}{ Observer dan $\%$} & \multicolumn{3}{l|}{ Rata-rata } \\
\cline { 3 - 9 } & P1 & $\%$ & P2 & $\%$ & P & $\%$ \\
\hline 1 & Memerhatikan penjelasan guru & 15 & 60 & 18 & 72 & 16,5 & 66 \\
\hline 2 & $\begin{array}{l}\text { Mengamati kegiatan koperasi } \\
\text { (kontruktivisme) }\end{array}$ & 20 & 80 & 19 & 76 & 19,5 & 78 \\
\hline 3 & Menjawab LKS(Inquiry) & 22 & 88 & 22 & 88 & 22 & 88 \\
\hline 4 & $\begin{array}{l}\text { Bertanya kepada pengurus } \\
\text { koperasi (bertanya) }\end{array}$ & 14 & 56 & 15 & 60 & 14,5 & 58 \\
\hline 5 & $\begin{array}{l}\text { Diskusi kelompok (masyarakat } \\
\text { belajar) }\end{array}$ & 13 & 52 & 13 & 52 & 13 & 52 \\
\hline 6 & $\begin{array}{l}\text { Presentasi hasi diskusi } \\
\text { (pemodelan) }\end{array}$ & 20 & 80 & 20 & 80 & 20 & 80 \\
\hline 7 & $\begin{array}{l}\text { Mengerjakan evaluasi } \\
\text { (penilaian autentik) }\end{array}$ & 25 & 100 & 25 & 100 & 25 & 100 \\
\hline 8 & Menyimpulkan materi(refleksi) & 17 & 68 & 16 & 64 & 16,5 & 66 \\
\hline Jumlah & 146 & 584 & 148 & 592 & 147 & 588 \\
\hline Rata-rata & 18 & & 18 & & 18 & \\
\hline Persentase & & 73 & & 74 & & 73,5 \\
\hline
\end{tabular}

Dari data pada tabel 2 dapat dilihat rata-rata aktivitas siswa pada masing-masing komponen pengamatan yaitu memerhatikan penjelasan guru $66 \%$, kontrukstivisme $78 \%$, inquiry $88 \%$, bertanya $58 \%$, masyarakat belajar $52 \%$, pemodelan $80 \%$, penilaian authentic $100 \%$ dan refleksi $66 \%$. Sehingga jika di rata-rata persentasenya adalah 73,5\% dikategorikan "baik". 
Tabel 4 Hasil Pengamatan Aktivitas Guru Siklus II

Tabel 3 Hasil Belajar Siswa Siklus I

\begin{tabular}{|l|l|c|c|c|}
\hline \multirow{2}{*}{ No } & \multirow{2}{*}{ Nama } & \multirow{2}{*}{ Nilai } & \multicolumn{2}{|c|}{ Keterangan } \\
\cline { 5 - 5 } & & & Tuntas & Tidak tuntas \\
\hline 1 & ER & 40 & & TT \\
\hline 2 & AV & 60 & & TT \\
\hline 3 & DN & 80 & T & \\
\hline 4 & AFP & 80 & T & \\
\hline 5 & ANA & 70 & & TT \\
\hline 6 & AA & 80 & T & \\
\hline 7 & ASP & 90 & T & \\
\hline 8 & BAPS & 80 & T & \\
\hline 9 & DW & 70 & & TT \\
\hline 10 & RW & 80 & T & \\
\hline 11 & DN & 60 & & TT \\
\hline 12 & GSA & 80 & T & \\
\hline 13 & HSR & 50 & & TT \\
\hline 14 & HCP & 80 & T & \\
\hline 15 & I & 80 & T & \\
\hline 16 & JAD & 70 & & TT \\
\hline 17 & K & 80 & T & \\
\hline 18 & MF & 50 & & TT \\
\hline 19 & MT & 60 & & TT \\
\hline 20 & NRM & 80 & T & \\
\hline 21 & NPW & 80 & T & \\
\hline 22 & NAP & 90 & T & \\
\hline 23 & PA & 90 & T & \\
\hline 24 & YFA & 80 & T & \\
\hline 25 & AlH & 70 & & TT \\
\hline Jumbh & 1.830 & T & -15 orang \\
\hline Rata-rata kelas & 73,2 & TT - 10 orang \\
\hline Persentase ketuntasan & $60 \%$ & & \\
\hline Persentase ketidaktuntasan & $40 \%$ & & \\
\hline & & & & \\
\hline
\end{tabular}

Berdasarkan hasil observasi aktivitas guru, aktivitas siswa, hasil belajar siswa siklus I, terdapat beberapa hal yang perlu direfleksi. Aktivitas guru pada siklus I, keterlaksanaan aktivitas guru adalah $55,71 \%$. Sedangkan dalam indikator keberhasilan penelitian disebutkan minimal $80 \%$. Ini berarti keterlaksanaan aktivitas guru belum meningkat dan perlu ditingkatkan pada siklus II. Kendala yang dihadapi adalah guru masih belum memahami pembelajaran dengan menggunakan pendekatan kontekstual. Sehingga guru masih sering melupakan tahapan dalam pembelajaran kontekstual. Aktivitas Siswa persentase aktivitas siswa pada siklus I mencapai nilai $73,5 \%$ dan masih belum memenuhi indikator kriteria ketuntasan keberhasilan minimal yakni $80 \%$. Beberapa kendala yang berhasil diidentifikasi oleh peneliti dan observer adalah: Siswa masih banyak yang belum memerhatikan penjelasan dari guru, berbicara sendiri dengan teman. Siswa, tidak serius ketika mengamati kegiatan di kopersi, tampak malu-malu ketika mengajukan pertanyaan sesuai LKS kepada pengurus koperasi dan siswa masih belum terbiasa melakukan diskusi kelompok.

\begin{tabular}{|c|c|c|c|c|c|c|}
\hline \multirow[b]{2}{*}{ No } & \multirow[b]{2}{*}{ Kategori Pengamatan } & \multicolumn{5}{|c|}{ Skor Perolehan } \\
\hline & & P1 & $\mathbf{P} 2$ & $\Sigma$ & $\begin{array}{c}\text { Rata } \\
\text { - } \\
\text { rata }\end{array}$ & $\%$ \\
\hline 1 & Memulai pelajaran & 5 & 4 & 9 & 4,5 & 90 \\
\hline 2 & $\begin{array}{ll}\text { Komponen } & \text { pembehajaran } \\
\text { kontekstual } & \\
\end{array}$ & & & & & \\
\hline & a. Kontruktivisme & 4 & 4 & 8 & 4 & 80 \\
\hline & b. Menemukan (inquiry) & 4 & 5 & 9 & 4,5 & 90 \\
\hline & c. Bertanya & 5 & 4 & 9 & 4,5 & 90 \\
\hline & d. Masyarakat belajar & 4 & 4 & 8 & 4 & 80 \\
\hline & e. Pemodelan & 4 & 5 & 9 & 4,5 & 90 \\
\hline & f. Penilaian autentik & 5 & 5 & 10 & 5 & 100 \\
\hline & g. Refleksi & 5 & 5 & 10 & 5 & 100 \\
\hline \multicolumn{2}{|c|}{ Jumlah } & 36 & 36 & $\overline{72}$ & 36 & 720 \\
\hline \multicolumn{2}{|c|}{ Rata-rata } & 4,5 & 4,5 & 9 & 4,5 & \multirow{2}{*}{90} \\
\hline \multicolumn{2}{|c|}{ Persentase } & 90 & 90 & 90 & 90 & \\
\hline
\end{tabular}

Berdasar tabel 4 aktivitas guru dapat dijabarkan sebagai berikut: aktivitas memulai pelajaran $90 \%$ dan komponen pembelajaran kontekstual yaitu kontruktivisme $80 \%$, inquiry $90 \%$, bertanya $90 \%$, masyarakat belajar $80 \%$, pemodelan $90 \%$, penilaian autentik $100 \%$, dan refleksi $100 \%$. Dengan skor rata-rata 4,5 dikategorikan „Sangat baik $^{\text {ee }}$. Rata-rata didapatkan dari penilaian indikator yang berjumlah 8 sesuai pendekatan kontekstual.

Tabel 5 Hasil Pengamatan Aktivitas Siswa Siklus I

\begin{tabular}{|c|l|c|c|c|c|c|c|}
\hline \multirow{2}{*}{ No } & \multirow{2}{*}{ Kategori pengamatan } & \multicolumn{3}{|c|}{ Observer dan \% } & \multicolumn{2}{c|}{ Rata-rata } \\
\cline { 3 - 8 } & & $\mathrm{P} 1$ & $\%$ & $\mathrm{P} 2$ & $\%$ & $\mathrm{P}$ & $\%$ \\
\hline 1 & $\begin{array}{l}\text { Memerhatikan penjelasan } \\
\text { guru }\end{array}$ & 20 & 80 & 22 & 88 & 21 & 84 \\
\hline 2 & $\begin{array}{l}\text { Membangun pemahaman } \\
\text { dengan mengamati kegiatan } \\
\text { koperasi (kontruktivisme) }\end{array}$ & 24 & 96 & 23 & 92 & 23,5 & 94 \\
\hline 3 & $\begin{array}{l}\text { Bertanyajawab dengan } \\
\text { pengurus koperasi }\end{array}$ & 22 & 88 & 22 & 88 & 22 & 88 \\
\hline 4 & Mengerjakan LKS (inquiry) & 23 & 92 & 23 & 92 & 23 & 92 \\
\hline 5 & $\begin{array}{l}\text { Melakukan diskusi } \\
\text { kelompok }\end{array}$ & 19 & 76 & 19 & 76 & 19 & 76 \\
\hline 6 & $\begin{array}{l}\text { Mempresentasikan hasil } \\
\text { diskusi kelompok }\end{array}$ & 22 & 88 & 22 & 88 & 22 & 88 \\
\hline 7 & Mengerjakan soal evaluasi & 25 & 100 & 25 & 100 & 25 & 100 \\
\hline 8 & $\begin{array}{l}\text { Menyimpulkan materi } \\
\text { dengan bimbingan guru }\end{array}$ & 21 & 84 & 21 & 84 & 21 & 84 \\
\hline Jumbah & 176 & 704 & 177 & 708 & 176,5 & 706 \\
\hline Rata-rata & 22 & & 22 & & 22 & \\
\hline Persentase & & 88 & & 89 & & 88 \\
\hline
\end{tabular}

Berdasarkan tabel 5 dapat diperoleh hasil rata-rata aktivitas siswa dalam pembelajaran yaitu memerhatikan penjelasan guru 84\%, komponen kontekstual yaitu kontruktivisme sebesar 94\%, inquiry sebesar $92 \%$, bertanya $88 \%$, masyarakat belajar $76 \%$, pemodelan $88 \%$, penilaian autentik $100 \%$ dan refleksi $84 \%$. Berdasarkan perolehan ratarata semua siswa sebesar $88 \%$ dengan kriteria sangat baik. 
Tabel 6 Hasil Behjar Siswa Siklus II

\begin{tabular}{|c|c|c|c|c|}
\hline \multirow{2}{*}{ No } & \multirow{2}{*}{ Nama } & \multirow{2}{*}{ Nilai } & \multicolumn{2}{|c|}{ Keterangan } \\
\hline & & & Tuntas & Tidak tuntas \\
\hline 1 & ER & 60 & & TT \\
\hline 2 & $\mathrm{AV}$ & 80 & $\mathrm{~T}$ & \\
\hline 3 & $\overline{\mathrm{DN}}$ & 90 & $\mathrm{~T}$ & \\
\hline 4 & AFP & 80 & $\mathrm{~T}$ & \\
\hline 5 & ANA & 90 & $T$ & \\
\hline 6 & $\mathrm{AA}$ & 80 & $\mathrm{~T}$ & \\
\hline 7 & $\overline{\mathrm{ASP}}$ & 90 & $\mathrm{~T}$ & \\
\hline 8 & BAPS & 80 & $\mathrm{~T}$ & \\
\hline 9 & DW & 80 & $\mathrm{~T}$ & \\
\hline 10 & RW & 90 & $\mathrm{~T}$ & \\
\hline 11 & $\overline{\mathrm{DN}}$ & 90 & $\mathrm{~T}$ & \\
\hline 12 & GSA & 80 & $\mathrm{~T}$ & \\
\hline 13 & HSR & 80 & $\mathrm{~T}$ & \\
\hline 14 & HCP & 90 & T & \\
\hline 15 & $\mathrm{I}$ & 100 & $\mathrm{~T}$ & \\
\hline 16 & JAD & 80 & $\mathrm{~T}$ & \\
\hline 17 & $\mathrm{~K}$ & 90 & $\mathrm{~T}$ & \\
\hline 18 & MF & 70 & & TT \\
\hline 19 & MT & 80 & $\mathrm{~T}$ & \\
\hline 20 & NRM & 90 & $\mathrm{~T}$ & \\
\hline 21 & NPW & 90 & $\mathrm{~T}$ & \\
\hline 22 & NAP & 90 & $\mathrm{~T}$ & \\
\hline 23 & PA & 80 & $\mathrm{~T}$ & \\
\hline 24 & YFA & 90 & $\mathrm{~T}$ & \\
\hline 25 & AIH & 90 & $\mathrm{~T}$ & \\
\hline \multicolumn{2}{|c|}{ Jumbh } & 2110 & \multirow{4}{*}{\multicolumn{2}{|c|}{$\begin{array}{l}\mathrm{T}=23 \text { orang } \\
\mathrm{TT}=2 \text { orang }\end{array}$}} \\
\hline Rata & rata kelas & 84,4 & & \\
\hline \multicolumn{2}{|c|}{ Persentase ketuntasan } & $92 \%$ & & \\
\hline \multicolumn{2}{|c|}{ Persentase ketidaktuntasan } & $8 \%$ & & \\
\hline
\end{tabular}

Berdasarkan tabel 6 dapat kita lihat ada 23 anak yang tuntas dan 2 anak yang belum tuntas. Terjadi peningkatan hasil yang signifikan dibandingkan dengan hasil pada siklus I dimana terdapat 10 orang yang tidak tuntas.

Tabel 7 Peningkatan Aktivitas Guru Siklus I-II

\begin{tabular}{|c|l|c|c|}
\hline \multirow{2}{*}{ No } & \multicolumn{1}{|c|}{ Aspek yang Diamati } & \multicolumn{2}{c|}{ SIKLUS } \\
\cline { 3 - 4 } & & I & II \\
\hline 1 & Kegiatan Awal & 3 & 4,5 \\
\hline \multirow{5}{*}{2} & Kegiatan Inti & & \\
\cline { 2 - 4 } & a. Kontruktivisme & 3,5 & 4 \\
\cline { 2 - 4 } & b. Menemukan & 3 & 4,5 \\
\cline { 2 - 4 } & c. Bertanya & 3,5 & 4,5 \\
\cline { 2 - 4 } & d. Masyarakat belajar & 3,5 & 4 \\
\cline { 2 - 4 } & e. Pemodelan & 4 & 4,5 \\
\cline { 2 - 4 } & f. Penilaian autentik & 4 & 5 \\
\hline \multirow{3}{*}{3} & Kegiatan Penutup & & \\
\cline { 2 - 4 } & a. Refleksi & 3,5 & 5 \\
\hline Jumlah & 28 & 36 \\
\hline Rata-rata & 3,5 & 4,5 \\
\hline Persentase & 70 & 90 \\
\hline
\end{tabular}

Berdasarkan tabel 7 skor rata-rata aktivitas guru siklus I sebesar 3,5 siklus II sebesar 4,5 berkategori sangat baik. Persentase keberhasilan siklus I adalah $70 \%$ dan siklus II adalah $90 \%$. Berdasar data tersebut diperoleh rata-rata $80 \%$ dengan kategori sangat baik.
Tabel 8. Hasil Pengamatan Aktivitas Siswa Siklus I-II

\begin{tabular}{|l|l|l|l|l|l|}
\hline \multirow{2}{*}{ No } & \multirow{2}{*}{ Aspek yang Diamati } & \multicolumn{4}{|c|}{ SIKLUS } \\
\cline { 3 - 6 } & & \multicolumn{2}{|c|}{ I } & \multicolumn{2}{c|}{ II } \\
\cline { 3 - 6 } & & P & $\%$ & P & $\%$ \\
\hline 1. & Memerhatikan penjelasan guru & 16,5 & 66 & 21 & 84 \\
\hline 2. & $\begin{array}{l}\text { Membangun pemahaman dengan } \\
\text { mengamati kegiatan koperasi }\end{array}$ & 19,5 & 78 & 23,5 & 94 \\
\hline 3. & Bertanya pada pengurus koperasi & 14,5 & 58 & 22 & 88 \\
\hline 4. & Menjawab pertanyaan LKS & 22 & 88 & 23 & 92 \\
\hline 5. & Melakukan diskusi kelompok & 13 & 52 & 19 & 76 \\
\hline 6. & Mempresentasikan hasil diskusi & 20 & 80 & 22 & 88 \\
\hline 7. & Mengerjakan evaluasi & 25 & 100 & 25 & 100 \\
\hline 8. & Membuat kesimpulan & 16,5 & 66 & 21 & 84 \\
\hline Jumlah & 147 & 588 & 176,5 & 706 \\
\hline Persentase & & 73,5 & & 88,2 \\
\hline
\end{tabular}

Berdasar tabel 8 diperoleh rata-rata aktivitas siswa siklus I sebanyak 18 siswa dengan persentase $73,5 \%$ bekategori baik. Siklus II sebanyak 22 siswa dengan persentase $88,2 \%$ kategori sangat baik. Maka diperoleh rata-rata aktivitas siswa sejumlah 20 siswa dengan persentase ketuntasan $80,8 \%$ berkategori sangat baik.

Tabel 9. Ketuntasan Individu dan Klasikal Per Siklus

\begin{tabular}{|c|c|c|c|c|c|}
\hline \multirow{2}{*}{ No } & \multirow{2}{*}{ Nama } & \multirow{2}{*}{$\begin{array}{c}\text { Siklus } \\
\text { I }\end{array}$} & \multirow{2}{*}{$\begin{array}{c}\text { Siklus } \\
\text { II }\end{array}$} & \multicolumn{2}{|c|}{ Ket } \\
\hline & & & & $T$ & TT \\
\hline$T$ & ER & 40 & 60 & & TT \\
\hline 2 & $\mathrm{AV}$ & 60 & 80 & $\mathrm{~T}$ & \\
\hline 3 & $\mathrm{DN}$ & 80 & 90 & $\mathrm{~T}$ & \\
\hline 4 & AFP & 80 & 80 & $\mathrm{~T}$ & \\
\hline 5 & ANA & 70 & 90 & $\mathrm{~T}$ & \\
\hline 6 & $\mathrm{AA}$ & 80 & 80 & $\mathrm{~T}$ & \\
\hline 7 & $\overline{A S P}$ & 90 & 90 & $\mathrm{~T}$ & \\
\hline 8 & BAPS & 80 & 80 & $\mathrm{~T}$ & \\
\hline 9 & $\overline{D W}$ & 70 & 80 & $\mathrm{~T}$ & \\
\hline 10 & RW & 80 & 90 & $\mathrm{~T}$ & \\
\hline 11 & $\overline{\mathrm{DN}}$ & 60 & 90 & $\mathrm{~T}$ & \\
\hline 12 & GSA & 80 & 80 & $\mathrm{~T}$ & \\
\hline 13 & HSR & 50 & 80 & $\mathrm{~T}$ & \\
\hline 14 & $\mathrm{HCP}$ & 80 & 90 & $\mathrm{~T}$ & \\
\hline 15 & I & 80 & 100 & $\mathrm{~T}$ & \\
\hline 16 & JAD & 70 & 80 & $T$ & \\
\hline 17 & $\mathrm{~K}$ & 80 & 90 & $\mathrm{~T}$ & \\
\hline 18 & MF & 50 & 70 & & TT \\
\hline 19 & MT & 60 & 80 & $\mathrm{~T}$ & \\
\hline 20 & NRM & 80 & 90 & $\mathrm{~T}$ & \\
\hline 21 & NPW & 80 & 90 & $\mathrm{~T}$ & \\
\hline 22 & NAP & 90 & 90 & $\mathrm{~T}$ & \\
\hline 23 & $\mathrm{PA}$ & 90 & 80 & $\mathrm{~T}$ & \\
\hline 24 & YFA & 80 & 90 & $\mathrm{~T}$ & \\
\hline 25 & AIH & 70 & 90 & $\mathrm{~T}$ & \\
\hline Jum & h skor total & 1.830 & 2.110 & & \\
\hline Nila & rata-rata & 73,2 & 84,4 & & \\
\hline Jum & h tuntas & 15 & 23 & 23 & \\
\hline Jum & $\mathrm{h}$ yang tidak tuntas & 10 & 2 & & 2 \\
\hline Per: & ntase siswa tidak tuntas & $40 \%$ & $8 \%$ & & 8 \\
\hline Per & entase ketuntasan klasikal & $60 \%$ & $92 \%$ & 92 & \\
\hline
\end{tabular}

Individu pada siklus I nilai rata-rata 73,2 , dengan persentase $60 \%$. Sedangkan pada siklus II nilai rata-ratanya 84,4 dengan persentase $92 \%$. Didapatkan rata-rata siklus I-II terdapat 2 siswa yang 
tidak tuntas yaitu siklus I sejumlah 10 siswa, siklus II sejumlah 2 siswa.

\section{Tabel 4.15. Rangkuman Data Siklus I-II}

\begin{tabular}{|l|l|c|c|}
\hline No & \multicolumn{1}{|c|}{ Aspek yang dinilai } & Siklus I & Siklus II \\
\hline 1. & Aktivitas guru & $70 \%$ & $90 \%$ \\
\hline 2 & Aktivitas siswa & $73,5 \%$ & $88 \%$ \\
\hline 3 & Hasil belajar & $60 \%$ & $92 \%$ \\
\hline
\end{tabular}

Pada siklus I komponen aktivitas guru yang memiliki nilai paling rendah adalah memulai pelajaran. Hal ini disebabkan guru belum mampu memulai pelajaran dengan baik. Komponen berikutnya yang memiliki nilai rendah adalah inquiri. Komponen lain yang memeroleh nilai rendah kedua dengan nilai 3,5 dengan kriteria cukup adalah kontruktivisme, bertanya dan refleksi. Disebabkan guru belum terbiasa dengan pembelajaran kontekstual sehingga masih belum lancar ketika melaksanakan tahapan dalam pembelajaran kontekstual. Berdasar data aktivitas guru pada siklus I, dapat diambil kesimpulan pembelajaran kontekstual telah terlaksana dengan kriteria kurang baik. Ini dapat dilihat pada hasil persentase aktivitas guru yakni $70 \%$, sedangkan indikator keberhasilan

adalah $80 \%$. Berdasarkan data tersebut maka aktivitas guru perlu dilakukan perbaikan pada siklus II. Komponen terendah siklus II adalah kontruktivisme dan masyarakat belajar dengan persentase $80 \%$. Persentase tertinggi adalah penilaian autentik dan refleksi dengan persentase $100 \%$. Pada siklus II rata-rata aktivitas guru adalah 90\%. Ini menunjukkan bahwa aktivitas guru telah melampaui indikator keberhasilan yakni $80 \%$.

Persentase terendah dalam aktivitas siswa siklus I adalah diskusi kelompok dengan jumlah $52 \%$. Komponen kedua yang memiliki persentase rendah adalah bertanya kepada pengurus koperasi dengan 58\%. Komponen berikutnya memerhatikan penjelasan guru dan menyimpulkan materi dengan jumlah persentase $66 \%$. komponen selanjutnya yang memiliki persentase rendah adalah mengamati kegiatan koperasi dengan persentase $78 \%$. Selanjutnya pemodelan $80 \%$, menjawab LKS dengan $88 \%$ dan komponen tertinggi adalah penilaian autentik dengan persentase $100 \%$. Maka diperoleh persentase rata-rata $73,3 \%$. Sehingga belum mencapai indikator keberhasilan yang telah ditetapkan sebelumnya yakni $80 \%$.

Hasil observasi pada siklus II hampir semua komponen pembelajaran kontekstual mengalami peningkatan. Hasil ini menunjukkan nilai yang diperoleh pada siklus II telah mencapai ketuntasan dengan rata-rata $88,2 \%$ karena indikator keberhasilan yang telah ditetapkan sebelumnya yakni $80 \%$. Dapat disimpulkan aktivitas siswa telah berhasil dan meningkat.

Hasil belajar siswa siklus I menunjukkan ada 15 siswa yang mencapai KKM dengan persentase $60 \%$ dan sisanya yakni 10 siswa tidak mencapai KKM dengan persentase $40 \%$ dengan rata-rata kelas 73,2 . Berdasar data tersebut hasil belajar siswa siklus I dapat dikatakan belum tuntas karena belum memenuhi kriteria yang telah ditetapkan yakni $80 \%$ siswa mencapai KKM.

Hasil belajar siswa pada siklus II didapatkan hasil belajar dengan nilai rata-rata 84,4 dengan persentase $92 \%$. Terdapat 23 siswa yang tuntas dan 2 siswa yang tidak tuntas dengan persentase $8 \%$. Hasil ini menunjukkan bahwa indikator keberhasilan telah tercapai sehingga dapat disimpulkan pembelajaran telah berhasil sesuai dengan indikator keberhasilan yakni $80 \%$.

\section{PENUTUP}

Aktivitas guru dalam pembelajaran kontekstual mengalami peningkatan dari siklus I ke siklus II. Pada siklus I aktivitas guru 70\% sedangkan pada siklus II menjadi $90 \%$. Terjadi peningkatan aktivitas guru sebanyak 20\%. Pada siklus I aktivitas siswa $73,5 \%$. Setelah dilakukan perbaikan maka pada siklus II aktivitas siswa lebih meningkat menjadi $88 \%$. Pada siklus I persentase hasil belajar siswa $60 \%$, pada siklus II menjadi $92 \%$. Nilai ketuntasan siswa secara individu dan klasikal menunjukkan peningkatan dari siklus I ke siklus II.

\section{DAFTAR PUSTAKA}

Alwasilah. 2006. Contextual Teaching and Learning. Bandung: Mizan Learning Centre.

Arikunto, Suharsimi. 2010. Penelitian Tindakan Kelas. Jakarta: Bumi Aksara.

Arikunto, Suharsimi. 2010. Prosedur Penelitian Suatu Pendekatan Praktik. Jakarta: Rineka Cipta.

Depdiknas. 2003. Pendekatan Kontekstual. Jakarta: Ditjen Dikdasmen.

Dimyati. 2006. Belajar dan Pembelajaran. Bandung: Remaja Rosdakarya. 
E. Mulyasa. 2007. Menjadi Guru Profesional. Bandung: Remaja Rosda.

Falance Theresa. 2001. Models and Strategies for Training Design: Constructivism. United States of America: International Society for Performance Improvement.

Gunawan, Rudy. 2011. Pendidikan IPS: Filosofi, Konsep, dan Aplikasi. Bandung: Alfabeta.

Hamalik. 2003. Proses Belajar Mengajar. Jakarta: Bumi Aksara.

Hanafiah \& Cucu Suhana. 2009 . Konsep Strategi Pembelajaran. Bandung: PT. Refika Aditama.

Hudojo. 2005. Pengembangan Kurikulum dari Pembelajaran Matematika. Malang: UM Press.

Hulett, Elwyn C. 2008. Action Research in the Classroom: Center for Teaching Excellence Grants and Statewide University Classes. New Mexico: Eastern New Mexico University Printing Services.

Ibrahim dan Nur .2010. Dasar-dasar Proses Belajar Mengajar. Surabaya: UnesaUniversity Press.

Jean, McNiff and Whitehead, Jack. 2002. Action Research: Principle and Practice. British: Taylor and FrancisGroup.

Jerolimek, J. And Parker. W.C. 2007. Sosial Studies in Elementary Education. New York: MacMillan Publising Company.

Johnson. B. Elaine. 2007. Contextual Teaching and Learning. Bandung: PT. Mizan.

Jonna Larsson. 2013. Contextual and Conceptual Intersubjectivity and Opportunities for Emergent Science Knowledge About Sound. IJEC (2013) 45:101-122. 5 Februari 2013.

Katz, Shana; Smith, Bettye P. 2014. Using Contextual Teaching and Learning in Foods and Nutrition Class. Proquest. 6 Oktober 2014.

Kevin J. Miller \& Milagros M. Sessions. 2005. Infusing Tolerance, Diversity, and Sosial Personal Curriculum Into Inclusive Sosial
Studies Classes Using Family Portrait and Contextual Teaching and Learning. Teaching Exceptional Children Plus, (Online), Vol. 1. Issues 3, January 2005, (http://www.file. Upi.edu), diakses 8 November 2014.

Kuswanto. 2005. Pendekatan Pembelajaran Modern: Contextual Teaching and Learning. Surakarta. Moleong, Lexy. J.M. 2007. Metodologi Penelitian Kualitatif. Bandung: Remaja Rosdakarya.

Muhibinsyah. 1995. Psikologi Pendidikan Suatu Pendekatan Baru. Bandung: Remaja Rosdakarya.

Muslich, Masnur. 2009. KTSP Pembelajaran Berbasis Kompetensi dan Kontekstual. Jakarta: Bumi Aksara.

Nurhadi. 2004. Pembelajaran Kontekstual dan Penerapannya dalam KBK. Malang: Universitas Negeri Malang. Pernyataan Standar Akuntansi Keuangan (PSAK) No.27 Tahun 1999 Tentang Akuntansi Perkoperasian.

Poedjiadi. 2005. Sains Teknologi Masyarakat: Model Pembelajaran Kontekstual Bermuatan Nilai. Bandung: Rosda.

Riyanto, Yatim. 2010. Paradigm Baru Pembelajaran: sebagai referensi bagi Guru/Pendidik dalam Implementasi Pembelajaran yang Efektif dan Berkualitas . Jakarta: Kencana.

Rosalin. 2008. Gagasan Merancang Pendidikan Kontekstual. Bandung: PT Karsa Mandiri Persada.

Saekhan, Muchith. 2008. Pembelajaran Kontekstual. Semarang: Rasail Media Group.

Sagala. 2003. Konsep dan Makna Pembelajaran. Bandung: Alfabetha.

Sanjaya. 2010. Strategi Pembelajaran Berorientasi Standar Proses Pendidikan. Jakarta: Kencana Pranada Mulia Group.

Santrock, J.W. 2007. Perkembangan Anak. Jilid 1 Edisi 11. Jakarta: Airlangga. 
Sapriya. 2009. Pendidikan IPS dan Konsep Pembelajaran. Bandung: PT. Remaja Rosdakarya.

Siswoyo, Dwi. 2007. Ilmu Pendidikan. Yogyakarta: UNY Pers.

Slameto. 2010. Belajar dan Faktor-Faktor yang Mempengaruhi. Jakarta: Rineka Cipta.

Smaldino, Sharon E, Deborah L. Lowther \& James D. Russell. 2007. Instructional Technology and Media for Learning . Jakarta: Kencana.

Suparno, Paul. 2010. Filsafat Konstruktivisme dalam Pendidikan. Jogjakarta: Kanisius.

Sudjana, Nana. 2008. Proses Belajar mengajar. Jakarta: Bumi Aksara.

Suhanadji dan Waspodo Tjipto S. 2003. Pendidikan IPS. Surabaya. Insan Cendekia.

Thompson, Julia.G. 2007. The First-Year Teacher's Survival Guide. Ready to Use Strategies Tools and Activites for Meeting The Challenges of Each School Day. Jossey Bass. Wintarti, Atik dkk. 2008. Contekstual Teaching and Learning Matematika. Jakarta : Pusat Perbukuan Departemen Pendidikan Nasional. 